\title{
. \\ Dialogue as a Means of Religious Co-Production: Historical Perspectives
}

\author{
Katharina Heyden (D)
}

check for updates

Citation: Heyden, Katharina. 2022. Dialogue as a Means of Religious

Co-Production: Historical

Perspectives. Religions 13: 150

https: / /doi.org/10.3390/rel13020150

Academic Editors: Claudia Welz,

Christian Wiese and Bjarke Mørkøre

Stigel Hansen

Received: 15 January 2022

Accepted: 31 January 2022

Published: 7 February 2022

Publisher's Note: MDPI stays neutral with regard to jurisdictional claims in published maps and institutional affiliations.

Copyright: (C) 2022 by the author. Licensee MDPI, Basel, Switzerland. This article is an open access article distributed under the terms and conditions of the Creative Commons Attribution (CC BY) license (https:// creativecommons.org/licenses/by/ $4.0 /)$.
Faculty of Theology, Institute for Historical Theology, University of Bern, 3012 Bern, Switzerland; katharina.heyden@theol.unibe.ch

\begin{abstract}
What does interreligious dialogue look like from different religious perspectives? What does it do? One way of answering these questions is by examining historical examples of "religious dialogue". These illustrate first-hand the rhetoric of interreligious dialogue. This article examines three case studies: (1) from 2nd-century Rome, Justin Martyr's Dialogue with Trypho; (2) from 12thcentury Spain, the Kuzari by Judah Halevi the Jew alongside the Dialogus of Petrus Alfonsi, a Christian convert from Judaism (both discuss Islam); (3) from 18th-century Berlin, Moses Mendelssohn's Jerusalem and Johann Caspar Lavater's Nathanael. Each contextualized case-study reveals the creative, morally enigmatic tension between commitment to hearing the religious Other, the utility of the Other for demarcating one's own religious identity, and the epistemological contradictions of religious systems. Borrowing Martin Buber's insight that the Ich (the "I") needs a Du (a "you") to form itself but must transform that $D u$ into a third person es (an "it"), this article shows how complicated a process religious co-production through dialogue is-one which is both morally problematic and ethically promising. Here, literary dialogues establish a general feature of interreligious dialogue: the requirements of self-construction, not just the need for peaceful coexistence, recommend the adoption of a strong dialogical tolerance.
\end{abstract}

Keywords: religious co-production; dialogue; Martin Buber; Justin Martyr; Petrus Alfonsi; Judah Halevi; Moses Mendelssohn; Johann Caspar Lavater

Rome, mid-second century: A Christian philosopher composes a literary dialogue based on a conversation he has had years earlier with a Jew in Ephesus. In that work, he elaborates for the first time an idea that would profoundly shape the self-understanding of Christians and their perception-and treatment-of Jews: the claim that Christians are the true people of God and the only legitimate heirs to all biblical promises.

Spain, early 12th century: Two of the most learned men of their age, both of Jewish origin but one a convert to Christianity, independently but almost simultaneously write dialogues involving Jews, Christians and Muslims. These two dialogues would shape the perception-and interaction — of Judaism, Christianity, and Islam in Europe for centuries to come.

Berlin, late 18th century: A Jewish philosopher receives a public letter and book dedication from a Christian pastor, a Swiss pietist whom he had met years before who was now summoning him to public religious debate. Although he rejects the summons, the affair of this dedication will forever reshape his perception-and treatment-as a Jew in the learned world of the Enlightenment, a legacy he will leave to posterity.

The above show three moments of religious co-production through literary dialogues that reflected and effected personal encounters between Jews, Muslims, and Christians. ${ }^{1}$

\section{The Necessary but Ephemeral Second-Person Perspective}

The dialogue has long been the preferred genre for literary debate between religions. ${ }^{2}$ Modern researchers and proponents of interreligious encounters, however, have difficulty with these texts, which do not meet today's standards for dialogue. Today, people in 
Western societies have rather particular ideas of what religious dialogue, whether between individuals or groups, should look like. Take for example the guidelines for interreligious dialogue provided by the Swiss Interreligious Thinktank: "Dialogue is a special form of communication, because it is reciprocal. It depends on a balance of listening and speaking, and is based on respect, empathy, mutual acceptance, and the acknowledgement that all the people involved must be regarded as equal partners in discussion." ${ }^{3}$ Such a conception of dialogue-and I could add myriad similar examples from both academic discourse and interfaith initiatives - owes a great deal to the dialogical principle laid down by Martin Buber in his "Ich und Du", though it does not always reach the depth of Buber's subtle reflections on the dynamics of identity formation. ${ }^{4}$

Measured against the contemporary ideal of interfaith encounter, literary dialogues from the past appear to represent an unacceptable, if not unethical, form of dialogue. In fact, these texts do not reflect real encounters between persons at all, but rather staged debates between invented figures: a single author with a given religious identity creates all the characters, inventing the religious Self (or Selves) and Other(s). Often, they create the Other precisely to legitimate and develop their own religious truth. Where is the required reciprocity, where the balance of listening and speaking, where the mutual acceptance in such a literary dialogue composed by one single author? Using Martin Buber's language, what happens in those texts can be explained thus: the You $(D u)$ of a real encounter is transformed by an author into an It (Es). The opponent (Gegenüber) is turned into an object (Gegenstand) and is therefore no longer capable of a real relationship. No wonder such works are no longer written today, and no wonder late antique and medieval controversial dialogues are viewed critically by modern academics and activists alike.

However, Martin Buber signals a crucial point which must not be underestimated: any attempt to shape the self depends on a counterpart, on a $\mathrm{Du}$. However, the effort of identity formation can only succeed if that counterpart is transformed into an object, by addressing the $D u$ as an Es. Buber emphasizes that humans cannot stand living in permanent relation to a $D u$-that they must convert the $D u$ into an Es from time to time in order not to burn out (verzehren) within a permanent Ich-Du relation. ${ }^{5}$ Indeed, according to Buber, orientation within the world and identity formation are only possible by an Ich that transforms the $D u$ into an Es in order to become an Ich. This, however, is precisely what happens when an author processes real encounters with religious others in a literary dialogue. They create their figures by reflecting real encounters with living counterparts, but throughout the writing process, the real $D u$ is transformed into an exemplary literary one. This, according to Buber, means that the $D u$ is turned into an Es that helps develop their argumentation in order to provide their audience with the coherent presentation of their own religious truth and tradition. Hence, literary dialogues can be considered instruments of religious identity formation. ${ }^{6}$

That way of producing religious identity is not a solitary process, however, but one which in turn opens up new dialogical fields-be it through direct or indirect reactions, immediately or in the long run. It is this dynamic of religious co-production through dialogue that I wish to discuss on the basis of the three aforementioned moments in history.

In doing so, I would like to contribute to an argument that Paul Mendes-Flohr presented in a 2017 essay entitled "Dialogue and the Crafting of a Multi-Cultural Society". This article takes a critical look at perceptions of tolerance that declare religious particularities accidental, superficial, and irrelevant against the background of a common humanity. Such a perception underlies, according to Mendes-Flohr, not only Lessing's "Nathan der Weise" but also "the tepid ethic of contemporary inter-faith tolerance" (Mendes-Flohr 2017, p. 311). With Stanley Fish and other critical thinkers of interreligious dialogues, MendesFlohr champions a "strong multiculturalism" that takes religious convictions seriously and considers them relevant for the crafting of pluralistic societies. With regard to religious believers, Mendes-Flohr raises questions such as the following:

Can an abiding fidelity to the theological positions and values of one's religious community allow one to acknowledge the cognitive and spiritual integrity of 
other faith commitments? The challenge is perhaps more poignant when formulated from the perspective of religious educators: How is one to instruct youth in the religious beliefs and values of their community, while encouraging them to be tolerant of beliefs and values different, and perhaps even incompatible with their own? How is one to educate youth to have firm moral and faith convictions, while encouraging them to honor opposing positions? (p. 310)

"A solicitous, dialogical tolerance", Mendes-Flohr states, "through which one actively seeks to acknowledge and understand the other-must thus perforce take its lead from a source other than a concern for civic harmony" (p. 315). For him, this source is to be found in the notion of "creatureliness as the theological ground analogous to the humanistic notion of a common humanity" (p. 316). Since all religions share an understanding of human beings as creatures, they also should have a mutual interest in each other's individual characteristics. Religious particularities then would no longer appear as things to be overcome but as expressions of the creatureliness of humans which need to be respected and the right to hold them protected for their own sake. With the following digressions into history, I would like to provide yet another source for an intrinsically motivated dialogical tolerance between religions-a source that turns out to be as strong as it is ambivalent. When looking into the dynamics of religious co-production through dialogue, we observe expressions of the will and need to form and reform one's own religious identity in relation to others, indeed by using others, by taking them into the service of one's own religious formation, or, to put it in Buber's terms, by making the $D u$ an Es in order to become an Ich. What might seem ethically questionable within written dialogues from today's perspective thus proves to be a simple fact that exposes powerful epistemological dynamics from a historical point of view. This can-and should, I will argue-in turn have ethical consequences. I say "should" because religious co-production is a phenomenon as ubiquitous as it is ambivalent with regard to both the individual historical moment and the long run of history. Since this applies in particular to the history of Judaism and Christianity, my miniature case studies start there.

\section{Three Moments of Dialogical Co-Production in Religious History}

\subsection{Justin and Trypho}

As far as we know, Justin was the first Christian author to compose a literary dialogue. Probably a descendant of Greek colonists in Neapolis, today's Nablus, Justin left Palestine during the Bar Kokhba revolt (132-135 CE) and established a philosophical school in Rome (Ulrich 2012; George 2012). He claimed to teach the "true and pure doctrine of Jesus Christ", as he explains to Trypho, the Jewish interlocutor in his Dialogus. ${ }^{7}$ The emphasis on "true" und "pure" already hints at the fact that Jews are not the only opponents the apologist had in mind when composing his work. At least as important were the many teachers and groups representing a diversity of Christian thinking in Rome at this time or, to adopt Justin's perspective, a vast variety of false and polluted doctrines that called themselves Christian. $^{8}$

The Dialogue with Trypho takes us to a time and place where the boundaries between what is "Jewish" and what is "Christian" were still being negotiated (Parvis and Foster 2007; more generally, see the "parting of the ways" debate in, e.g., Dunn 2008; Becker and Reed 2003). While Justin could already use these terms and assign them to different groups and teachings, how to define them concretely was still far from fixed in his time. Clarifying their relationship to Judaism had become urgent for Christians in the first half of the second century for several reasons: on the political level, with the Bar Kokhba revolt, it became vital for Christians to prove that they were not Jews and thus not dangerous to the Romans. On the theological level, various "Gnostic" teachers and groups, most prominently Marcion and his followers in Rome, had propagated a type of Christianity more radically different from Judaism than what would later be deemed orthodoxy. In this context, Justin's Dialogus can be read as an attempt to sort through religious diversity and to develop a coherent understanding of Christianity within a vast ocean of sometimes uncomfortably 
proximate alternatives. This would explain well the rather weak structure of the text, which puzzled modern scholars starting with Adolf Harnack (1913, pp. 47-96; more recently see Lieu 1996, pp. 103-53; den Dulk 2018). What begins as a Platonic dialogue between two philosophers increasingly becomes a digressive meditation and a circling introduction to the interpretation of the Scriptures (Heyden 2009; Lang 2016).

Starting with the spotlight on Justin walking around in a portico $(\pi \varepsilon \rho \iota \pi \alpha \tau o \tilde{v} v \tau i$ $\mu \mathrm{ol}$

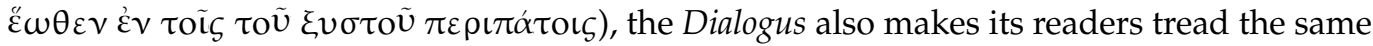
path around the marketplace of philosophical options. Throughout the dialogue, the same themes-Law, Circumcision, Covenant, Christ, and the Land-recur again and again without a clear line of argument. Not least because of this wandering literary character, scholars have intensively debated the intended audience. Should we imagine Pagan, Jewish, or Christian readers? ${ }^{9}$ I find it most plausible to take the work as a kind of textbook in the context of Justin's school-an introduction to the interpretation of Scripture for Justin's students, who were mostly Christians (Heyden 2009). This would explain not only the transformation of a philosophical dialogue into an exegetical-doctrinal discourse, but also the open-ended nature of the work. The Dialogus does not result in the Jews converting or assenting to Christianity, but in mutual assurance that both parties would be interested in continuing the conversation. ${ }^{10} \mathrm{I}$ understand this as a call to the (Christian) reader to continued intellectual engagement with Judaism. It seems clear to Justin that any Christian teaching and practice has to be shaped and legitimized in relation to Judaism. To imagine and shape Christianity as fundamentally non-Jewish, as Marcion had proposed, would lead to the Gnostic rejection of the incarnation. However, this idea was central and indispensable to Justin's "true and pure doctrine". With his Dialogus, Justin modeled a Christian engagement with Judaism which could help not only to supersede and encompass Judaism within a totalizing Christian view of reality but at the same time identify and fight Christian deviant teachings. The whole dilemma of the relationship between Judaism and Christianity that would shape two millennia of shared history is already articulated in nascent form here, both in narrowly theological and in wider socio-political terms.

In the narrative frame of the Dialogus, Trypho introduces himself to Justin as a "Hebrew of the circumcision" looking to benefit from philosophical conversation. In contrast to Justin, Trypho is accompanied by a crowd of followers (which might make readers think of a sophist from the Platonic dialogues). However, Justin stages a meaningful difference between the Jewish crowd and the individual Jew. While Trypho is portrayed as highly educated, interested and courteous, his followers burst out laughing twice when Justin reveals himself to be a Christian (Dialogus ch. 8.2; 9.2). Is the reader to conclude that many Jews together are dangerous, while a single one may be a beneficial conversation-partner to Christians? At least, that is how the Dialogus works.

With regard to the Jews as a group, Justin accuses them of being responsible and guilty for the bad reputation that Christians have in Roman society: "You selected and sent out from Jerusalem chosen men through all the land to tell that the godless heresy of the Christians had sprung up, and to publish those things which all who knew us did not speak against us. ( . . . ) So that you are the cause not only of your own unrighteousness [ $\dot{\alpha} \delta \iota \kappa i \alpha \varsigma$

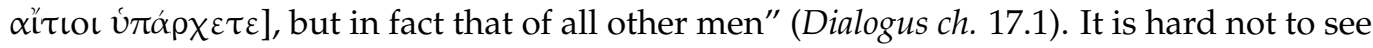
such words as precedents to later anti-Jewish conspiracy theories. Moreover, Justin adds to this accusation the more theological idea that this behavior against the Christians is to be seen as a continuation of previous behavior which brought about the crucifixion of Jesus (for which Justin holds the Jews responsible).

This negative image of the Jews as a group is contrasted with Trypho as an individual. He does not believe in the scare stories that his fellow Jews spread about Christians. On the contrary, Trypho is portrayed as educated, eager to learn, and very gentle. Some scholars have taken this to indicate that there is a historical person behind the literary figure. ${ }^{11} \mathrm{I}$ do not think that the evidence provides any secure answer on that question, but it is more important to note the function of this positive characterization within the Dialogus. Trypho the Jew, although the foil to many of Justin's thoughts, actually becomes the motor for the 
development of a Christian interpretation of the Scriptures as the Dialogus progresses. He asks questions, makes objections, and confirms statements in a way that is actually not always plausible for a Jew but which does push Justin's argument forward. Trypho the Jew serves, we could say, as a "pedagogue" $(\pi \alpha \iota \delta \alpha \gamma \omega \gamma \delta$ s $)$ in the original sense of that word: someone who leads the student to the teacher, in this case leading the reader to Justin the Christian philosopher.

It is remarkable, though, that earlier in the Dialogus, when it comes to the question of the preexistence of Jesus Christ, Trypho objects: "Oh Sir, it were good for us if we if we had been persuaded by those who taught us, who laid down a law that we should have no intercourse with any of you and should not have even any communication with you on these questions". 12

By putting these words into the mouth of his Jewish figure, Justin shows a certain sensitivity to the fact that interest in theological engagement with the other might be only one-sided: Jews might have no interest or need to engage with Christianity. However, this awareness does not prevent Justin from forcing his Jewish figure to play its part in service of Christian self-reflection (and if there is a conversion of the Jew at the end of the dialogue at all, it is that the Jews endorse this function by expressing hope for further conversations like this). In fact, with Trypho, Justin has created a Jewish figure who stands not only for Judaism ex circumcisione but who also represents all Christian heresies that Justin aims to reject. The effect of that strategy is to sort out simultaneously what might be a convincing Christian understanding of the biblical prophecies. To a large extent, the Dialogus operates on the concept of the Jewish both within and outside of Christianity. Justin constructs the figure of the Jew alongside notions of Christian identity to the same extent that he uses biblical and "Jewish" concepts to form a "true and pure" Christian identity. In doing so, he creates both the pure Christian and the pure Jew.

Throughout Justin's Dialogus, the notion of "Jewish" becomes a crucial means, a critical category that aids orientation within the ocean of religious diversity in the second century and beyond. Paradoxically, this category serves to attack both Jews and Gnostics, by accusing them of the same error: namely, separating too sharply the material world from the spiritual. In the case of the Gnostics, this would lead to a rejection of everything material or corporal. In the case of the Jew, the same error results in an obsession with everything carnal and in blindness to the spiritual sense of Scripture. As both are unable to accept the idea of divine incarnation, they can be represented by one and the same character-a Jew. Thus, "Jewishness" has become an intellectual tool to measure any heretical thinking within and outside Christianity (see Nirenberg 2013 on the history of this kind of hermeneutics; see Chapter 3 for Justin). A "Jew" in the strong sense is one who denies Jesus to be the Christ, whereas to observe "Jewish" laws does not exclude Christ-believers from salvation, as long as they do not force others to become obedient as well (in this tolerance towards "Judaizing", the Christian mainstream would not follow Justin). ${ }^{13}$

The ambivalent representation of the Jew(ish) would deeply shape Christian thinking about and attitudes towards Judaism. Not that many Christians would have read Justin's Dialogus (of which actually only one manuscript remains), but later Christian writers of greater range and influence, such as Irenaeus and Tertullian, took over Justin's main arguments and accusations and presented them in more systematic, memorable, and effective ways (see Mach 1996 on the reception of Justin's Dialogus in later Christian literature). Because of this reception, Justin opens a long series of controversial works staged as dialogues with Jews by Christian authors. However, Jews are rarely the target audience of such works, and by no means are all of those dialogues motivated by real encounters (see inter alia Limor and Stroumsa 1996; Morlet et al. 2013). As in Justin's case, the figure of the Jew serves as theological opponent and at the same time as a promoter for Christian self-reflection. In this sense, those literary dialogues are testimonies to religious co-production and are as valuable as they are ambivalent. They show that Christians have often developed their own teachings in relation, both in connection and in opposition, to Judaism regardless of whether or not they were actually confronted with real Jews in their 
own lives. They created their Jewish figures in the way that was most suitable for the development of their own religious teachings. By doing so, they co-produced themselves as Christians and the Jews they needed in order to develop and legitimate their specific understanding of Christianity. However, they produced not only images of Jews, but also socio-political realities for real Jews, because the literary images of Jews and Judaism that they created influenced Christians' perceptions of their Jewish neighbors in real life and, in the end, also affected social and political decisions and behavior.

As for this interaction between shaping the imagination and shaping reality, it is disturbing to note how the literary distinction between the dangerous crowd of Jews and the useful individual Jew in Justin's Dialogus is mirrored in the realities of medieval Christian societies, with a very few singular Jews in the service of Christian kings on the one hand and many laws that fixed precarious living conditions for the Jewish population on the other. This is to say nothing of the aftermath of Justin's historico-theological reasoning, namely the claim that the destruction of Jerusalem and the exile of the Jewish population after the Bar Kokhba revolt was God's punishment of the Jews for having crucified Jesus and for continuing to deny him. This idea would loom large in later relationships between Jews and Christians. Ironically, Justin himself basically recognized and addressed this kind of slander-based interaction when he accused the Jews of being to blame for the bad reputation and even persecution of Christians in the Roman Empire because of the slander and rumor they spread about them. A balanced historical judgment must take into account that this accusation must inform Justin's representation of the Jews in his Dialogus, and we should not forget the fact that Justin himself was killed by the Romans as a Christian inciter.

\subsection{Petrus Alfonsi and Jehuda Halevi}

The beginning of the 12th century saw radical changes in the coexistence of Muslims and Jews in al-Andalus. While in the 11th-century Taifa kingdoms Jews enjoyed access to education and political power (which, however, did not protect them from massacres such as the one in 1066 Granada), the new Almoravid rulers removed Jews from high office and tried to limit their social and political mobility. Although these restrictions were less drastic than they would become under the Almohads later in the century, they still caused many distinguished Jews to immigrate to the Christian realms in Europe or even to the Mediterranean. Among these were a certain Moses, who later took his Christian name Petrus Alfonsi, and Jehuda Halevi, two of the most renowned and educated members of the Jewish communities in al-Andalus. The two might not have known each other and they indeed struck two contrary paths, not only geographically but also with regard to religious thinking, after leaving al-Andalus. Peter Alfonsi was baptized as a young man in his twenties and enjoyed a successful career as an Andalusian scholar in France and England. Yehuda Halevi left al-Andalus for the Holy Land as a renowned Jewish scholar toward the end of his life. Nevertheless, both men present their own religious commitments in the medium of a literary dialogue that brings Judaism, Christianity, Islam, and philosophy onto one stage, and both have had a tremendous impact on the shaping of their own religious communities and on perceptions of their respective others, for both pre-modern and modern readers alike. ${ }^{14}$

The two works have rarely been compared in previous research, ${ }^{15}$ but to do so can be instructive in analyzing the dialogical co-production of religions. Although the two works pursue opposite goals, they have a great deal in common.

Affinities start with literary staging and multilateral perspective. Both works look back to a realized conversion and use the convert as a disciple, and as an exemplary reader, to be taught (Hughes 2007; Ravitzky 2019). Petrus Alfonsi wrote his Dialogus in response to the fact that his baptism 1106 in Huesca sparked controversy within his former Jewish community. The Dialogus was meant to set out his intention and reason (intentio et ratio) for this conversion and is staged as an encounter between Alfonsi's former Jewish Ego Moses and his new Christian one, which he calls by his baptized name Peter. ${ }^{16}$ The whole dialogue is thus a reappraisal of Alfonsi's own conversion and a self-justification given 
face-to-face with his former religious self. By this staging, it goes without saying from the very beginning that, in the end, Moses will convert. The same is true in a different way for Jehuda Halevi's Kuzari. Here, it is also clear from the beginning that the king will convert to Judaism. The history of the Black Sea kingdom of Khazaria, whose king converted to Judaism in the eighth century, established a Jewish kingdom for almost two centuries, provided an attractive narrative frame for the dialogue. At the same time, this relieved Halevi from the obligation of dealing with Jewish authorities from later than the eighth century (Schweid 2007).

The unnamed king ${ }^{17}$ has a vision at night in which God reveals to him that he is pleased with the ruler's pious intentions but not with his actions. The king decides to seek advice from all the wise men in his kingdom except the Jews, whose precarious status and low reputation in the world are taken as proof of their religion's inferiority. However, as neither the philosopher nor the Christian nor the Muslim succeed in convincing the king of their doctrine, the king comes back to Judaism and chooses a learned master (זבר) as his spiritual instructor.

Both Peter's Dialogus and Halevi's Kuzari reflect the immense influence philosophical reasoning had on religious education and interreligious conversation in medieval Spain. Peter presents Christianity to his readers as the religion with the greatest affinity for reason. Halevi unfolds Judaism as a historical religion superior to philosophical reasoning. To achieve these goals, both authors take a universal approach and, through dialogical confrontation with Judaism, Christianity, Islam, and philosophy, develop their specific interpretations of their own religious tradition and situate them within their respective communities. Halevi designs his view of Judaism over and against the Karaites, ${ }^{18}$ and Alfonsi aims to introduce scientific knowledge (and presumably also himself as the teacher of this knowledge) into Latin Christianity. Each in his own way, both authors contributed greatly to the perception of Judaism as a rather un-rational (if not irrational) religion-and, vice versa, of Christianity as a guardian and bride of philosophy.

Both describe, or rather construct, Judaism as the religion of the Talmud, although with opposing value-judgements. According to Alfonsi, the Talmud distorted biblical Judaism and must therefore be proven as incompatible with reason. This allows the author, as a Jewish convert to Christianity, to maintain fidelity to the Old Testament and at the same time use it as an argument against contemporary Judaism. Interestingly, he only relies on haggadic material from the Talmud ${ }^{19}$, and it is almost always Peter, the Christian, who brings this material into the conversation. Halachic texts play no role, as they are probably regarded as irrelevant for the Christian reader. Instead, Peter states that after the destruction of the temple, Jews could no longer fulfill the Law for the simple reason that the conditions for sacrifice and priestly services were taken away together with the temple (Dialogus Titulus 4.1-12; cf. 2.1-29; 9.19-58). Any attempt to replace and recontextualize the Law within a time and place aside from the Temple is therefore vacuous and even irrational according to Peter. The main accusation against the Jews is not the traditional one, established by Justin, that Jews had crucified Christ because they did not recognize him as the Messiah. The main charge is rather that they did not realize the real meaning of the destruction of the temple, much as they do not understand the real meaning of their own Scriptures. Most of the Dialogus is therefore dedicated to explaining the Hebraica veritas. At the very beginning, Alfonsi has Moses say: "If you cite the authority of Scripture, you may do so according to the Hebrew truth (secundum ueritatem Hebraica). For if you do otherwise, you must know that I will not accept it".$^{20}$ This demand, which is accepted by Peter, implies two things: first, that the discussion should be limited to the First Testament; second, that the Hebrew text should be used as its only textual basis. ${ }^{21}$ Alfonsi's dialogue resolves both of these issues in a hitherto unprecedented way and thus provides Latin Christianity with unknown methodologies and hermeneutics-not only with regard to Judaism but also with regard to a Christian understanding of Scripture. Alfonsi makes intensive use of the Bible, including almost all its books and referring to all of them as prophetic Scriptures. His goal is to show that the whole Old Testament testifies to Christ. ${ }^{22}$ 
This is as much a lesson for Christians as it is a statement against the Jews. Unlike Peter Abaelard, who propagated reason alone (sola ratione), Alfonsi wants to demonstrate the concord of Scripture and reason. His maxim that Scripture (or God) never employs any word without reason appears three times in the Dialogus (Titulus 11.29, 34; 12.60). By combining exegesis and science, Alfonsi provides for Latin Christianity an essential virtue and a strength of Andalusian scholarship.

It is interesting to note that a quite similar idea of Christianity is also present in the Kuzari: the Christian emphasizes more than once that Christians acknowledge all that is written in the Torah and consider it "truly divine". He claims Christians to be the heirs of the true Israelites and quotes Matthew 5:17 in order to prove loyalty to the Torah. However, if the Kuzari judges Christianity to be totally irrational and unacceptable for anyone who has neither experienced visions that led him to believe nor inherited such beliefs from parents, it is not targeting the status of the Torah within Christianity. Rather, here, it obviously refers to the statement that Christ is "outside a human, inside a God, outside a sent prophet, inside a sent God" (I.4). Thus, Halevi allows his Christian dialogue-partner to affirm the divinity of the Torah, which will become central to the unfolding of Judaism throughout the Kuzari.

With regard to previous anti-Jewish polemics, it is also noteworthy that Alfonsi does not make use of the motif of Jewish blindness, as so many Christian authors had in the line of Justin and Augustine (see Augustine, De civitate Dei 6.48-51). On the contrary, Alfonsi claims that the Jews crucified Jesus in full awareness of his being the Messiah and that they did so according to God's order and will, "so that he, just as he is the creator, would become also the redeemer of the whole holy church of believers". ${ }^{23}$ This turns out to be a deeply ambivalent statement. On the one hand, it makes the Jews active protagonists in God's salvation of the world-an argument that Alfonsi probably knew from Jewish apologetics against Christian accusations (Tolan 1993, p. 20). On the other hand, it makes the Jews conscious and voluntary murderers of God and thus exacerbates traditional accusations against the Jews as Christ-killers. For Alfonsi, the Jews knew what they were doing. This argument serves to portray the Jews as a conspiratorial group acting against Christianity.

Given their shared Andalusian background and the political and cultural domination of Islam therein, neither Alfonsi and Halevi could avoid including Islam as a religion or Arab scholarship in science and philosophy in his dialogue. It is all the more striking, though, that neither of the two gives Islam much space or its own voice. This shared feature begs for interpretation. In the Kuzari, the Muslim serves mainly to point the king to the Torah. In his very short summary of the tenets of Islam (I.5), the divinity of the Qur'an appears to be the most important point. However, as the king questions whether God might speak or otherwise connect directly with a human being, the Muslim refers to the fact that many miraculous events that appear in the Qur'an are also described in the Torah and are therefore trustworthy. However, the Kuzari does not take this as a proof in favor of Islam but rather as a hint that one must go back to Judaism to locate the "ground of proof and support" for all believers. Thus, the Christian and the Muslim together drive the Kuzari-both the king as main character of the dialogue and the book itself-into the arms of Judaism (I.4-10).

In Alfonsi's Dialogus, Titulus V, Islam comes into the play after Petrus has convinced Moses of the superiority of Christianity over Judaism. Moses declares himself ready to take up the role of a spokesman of Islam (enim in me eorum personam suscipiam), because he is wondering why Peter preferred Christianity to Islam, since "you have always had intercourse with its followers, have been educated among them, have read their writings, and understand their language". ${ }^{24}$ In favor of Islam, Moses emphasizes that Islamic Law is based on the unwavering foundation of rationality (inuenies super inconuulse fundamentum rationis fundatam) and promises wellbeing on Earth and in heaven.

In his reply, Petrus dissolves the connection between Arab culture and scholarship on the one hand and Islam as a religion on the other-a connection which seems to be taken for granted in Moses' presentation of Islam. In Titulus V (as well as across the whole Dialogus), 
Petrus hardly speaks of Arab writings and scholarship with regard to Islam. Instead, he limits the discourse to a deprecating and polemical presentation of the life and character of Muhammad, based on the ninth century Christian Risâla of al-Kindî. Muhammad appears as a man of dubious background, obsessed with power, who pretends to be a prophet in order to become king - that is, a man who uses religion for political goals (note that Petrus confronted himself with the accusation of having converted to Christianity only for dubious worldly reasons; see Dialogus Prologus I.4-5). By separating Arab culture from the Muslim religion, Alfonsi makes his Andalusian education and the high standard of Arab knowledge available for a rational justification of Christianity while at the same time discrediting Islam as the religion of the dubious Muhammad (as analyzed by (di Cesare 2015); see the shorter version in (di Cesare 2014).

In summary, both Alfonsi and Halevi present rather similar images of Judaism and Christianity, even if they, of course, ultimately reach contradictory judgments on the two religions. Judaism appears as the religion of the Talmud, with a strong emphasis on haggadic traditions and therefore highly linked to the Torah and the interpretation of Scripture, rather than a religion of halakhic law. Christianity is also presented as a religion of Scripture, namely the Torah, whereas the New Testament plays a marginal role in both texts. For both, reason has to decide on the credibility of a Christological interpretation of the Bible. The Kuzari is quick to dismiss Christology as unreasonable— "Here is no room for reason!" (I.5: א'ן בכאן מקום לסבראץ) -though at the same time it questions the importance of reason with regard to Judaism in arguing against the Karaites (Malachi 2018; Halper 2017; Langermann 1997). Alfonsi, in contrast, writes his Dialogus precisely to present the Christian interpretation of the Torah as reasonable, betraying that this was not a self-evident or undisputed view of Christianity at that time.

Juxtaposed, the two works present quite different pictures of Islam. While in the Kuzari, the Muslim's statements serve as the decisive precursor for turning to the Torah and thus to Judaism, Alfonsi directs focus away from the Qur'an and focuses entirely on (the polemical distortion of) Muhammad as a person.

What lessons can we learn about religious co-production from this moment in history and the mutual hermeneutics that emerged from it? The first lesson is that the arena of religious co-production between Christianity, Judaism, and Islam in medieval Spain was largely comprised of the interpretation of the Torah as a prophetic book. The New Testament and the Qur'an hardly play a role in either work, although both authors reveal knowledge of those Scriptures. This might not be very surprising, as the Torah is the only Scripture on which Jews, Muslims, and Christians commonly rely. However, in comparison to previous and contemporary Jewish-Christian controversies in the Latin West, this limitation of common ground is new. The second insight is related to this and regards the relation between culture and religion, which is very much debated in research on religion today. We have seen how Alfonsi strives to keep Arab culture and Islam apart in order to take advantage of Arab education and scholarship for his development of a scientifically and philosophically informed Christianity. Halevi, on the other hand, writes in Arabic but challenges the idea of the untranslatability of the Qur'an, as this makes the Qur'an inaccessible to non-Arabs (Kuzari I.6).(the fact that this argument could actually also be applied to the Torah, interestingly enough, does not matter in the Kuzari).

The most important insight, though, concerns the relation between inter and intrareligious processes of co-production and leads us back to the dynamics we have already observed with Justin. As we have seen, neither Halevi nor Alfonsi writes only, or even primarily, in defense of his own fixed Judaism or Christianity against other religions, but rather each tries to present his own specific interpretation of his respective religious tradition. In fact, in both works, the religious "others" appear only at the beginning, as if they were necessary for marking off the field for the argumentative battles to follow. The largest space in each dialogue is then taken up by the unfolding of the specific religious perspective and identity which the author aims to implement within his own religious tradition, over and against divergent currents or sects (or whatever you want to call them). 
In fact, developing their specific types of Judaism and Christianity and situating them within their respective audiences and communities seems to be the most important goal for both Halevi and Alfonsi. We can conclude that religious others who can clearly be differentiated from each other by name (which is the case with Jews, Muslims, Christians, or, as the Kuzari calls them, Jews, Ishmael, and Edom) serve-or are conscripted into service for-the formation of sectarian identities within those clearly distinguished communities. To put it in other words: interreligious confrontation not only serves the co-production of different religions, but also has effects - and sometimes to a greater extent-on intrareligious differentiation and formation.

That this is true of Alfonsi and Halevi is shown by their broad reception within Christianity and Judaism, respectively, over centuries. ${ }^{25}$ With regard to the latter, David Sorkin states that the book of Halevi was the most influential source of Moses Mendelssohn's view of Judaism (Sorkin 1998, p. 58) and, according to Adam Shear, Mendelssohn's distinction between eternal and historical truths goes back to the Kuzari.

\subsection{Johann Caspar Lavater and Moses Mendelssohn}

In the first days of September in 1769 in Berlin, the renowned enlightenment philosopher Moses Mendelssohn received a book delivery from Switzerland. It was sent by the Reformed pastor Johann Caspar Lavater from Zurich. The shipment contained a German translation and annotation of the last seven chapters of Charles Bonnet's Idées sur l'état futur des êtres vivants, ou Palingénésie philosophique (Bonnet 1769; 2002). In this work, the Genevan natural scientist had presented his germ theory and from this had derived the idea that all living beings would develop and perfect themselves towards a harmony of the universe. Based on his plant experiments, Bonnet saw himself confirmed in the assumption that human beings would live on after death in a new soul-body existence, and not only in a mere spiritual way as was asserted by the philosophical doctrine of immortality. Bonnet himself, and the pietist-influenced Lavater to a much greater extent, saw in germ theory a scientific proof of the Christian belief in corporal resurrection. In his annotations to the book entitled Untersuchung der Beweise für das Christentum, Lavater had transferred the idea of germ theory to Jesus Christ as the archetype and model of the new man, to whom mankind must conform in order to contribute to the harmony of the universe.

Why did Lavater dedicate his work to Mendelssohn? The two men are likely to have met three times a few years earlier in Berlin without developing a deeper relationship, although Lavater expressed a very positive impression of the "Jud Moses", as he calls Mendelssohn in his travel reports. ${ }^{26}$ With his printed letter dedication (Lavater 1769), Lavater obviously intended to open a public dialogue with Mendelssohn about Bonnet's work (finally, a genuine dialogue, a dialogue in the modern sense, one might think, a dialogue in which both sides can express themselves autonomously and reciprocally). In fact, in his dedication, Lavater not only praises Mendelssohn's admirable character, rigor of mind, and gentle humility, but also asks him to carefully and most critically examine the work and-what goes beyond that topos-to refute it publicly if he did not find its essential reasoning in favor of Christianity correct. However, only one ready to ignore the social status of Jews in Prussia and Switzerland at that time, and who therefore does not realize what a precarious position Lavater put Mendelssohn in with this invitation, could think of it as an offer for dialogue in the modern sense ("dieselbe öffentlich zu widerlegen, wofern Sie die wesentlichen Argumentationen, womit die Thatsachen des Christentums unterstützt sind, nicht richtig finden" Hirzel 2002, p. 234).

In fact, Lavater placed this dialogue in a specific light from the very beginning when he addressed Mendelssohn as "an Israelite in whom there is no deceit" ("Israeliten, in welchem kein Falsch ist" Hirzel 2002, p. 233). At a stroke, and for the first time in his life, Mendelssohn was publicly set before a glaring spotlight as a Jew. Up to that point, he had always treated his Jewish religion as a private matter and had appeared in public only as a philosopher. Lavater must have been very aware of what he was doing by "asking and imploring" Mendelssohn to read the Scripture not with philosophical impartiality — but as 
a Jew; ${ }^{27}$ what is more, "an Israelite in whom there is no deceit" is an allusion to Nathaniel, the first Jew to acknowledge Jesus as the Son of God and King of Israel in the Gospel of John (1:47). With this scriptural allusion, Lavater seems to hint at a hope-a hope only vaguely expressed in the dedication and which has puzzled contemporary and later readers: was he aiming at conversion when he urged Mendelssohn to do "what Socrates would have done if he had found this writing situated and irrefutable" ("was Socrates gethan hätte, wenn er diese Schrift gelesen, und unwiderleglich gefunden hätte" Hirzel 2002, p. 234)? Lavater rejected this accusation, but he was hardly believed, either by his contemporaries or by modern scholars. However, with regard to religious identity formation, his dedication can also be understood not as a call to conversion, but as an attempt at religious co-production through dialogue. Inspired by the Pietist movement, Lavater was convinced that the Jews would play a special role in the coming of Christ's kingdom (on the role of Jews in Pietest theology see Martin 2012; Holthaus 2009; Vogt 2007), and he recalled that Mendelssohn had spoken favorably about Jesus' moral character during a private meeting in Berlin. If we take Lavater's self-statements in the controversy seriously-and why should historians not do so sometimes? - then we can understand his dedication as a request for philosophical confirmation from Mendelssohn, the Jewish philosopher, rather than a call to confessional conversion. Not that this would have made the matter less problematic. On the contrary, such a service ${ }^{28}$ had been the subtle function that Christians had assigned to Jews for centuries: Jews, precisely in remaining Jews-and as such being subject to social ostracismbear witness to and confirm Christian messianism and eschatological hope. ${ }^{29}$

Mendelssohn, at any rate, perceived Lavater's dedication as a public invitation to conversion, and so did many other readers, as correspondence from those weeks shows, among them people such as Herder, Lessing, Nicolai, Lichtenberg and Goethe, and not least Bonnet himself (Rabidowicz 1974, pp. 295-374; Hirzel 2002, pp. 206-25). In a letter to Lavater from September 26, Bonnet pointed out that he had written his Palingénésie "solely for the unbelievers who were born in the bosom of the church", but not with regard to Jews ${ }^{30}$ (the question of who was reading the work as who, and how the self-understanding of readers would shape the perception of the work, became central throughout the controversy, and it is striking to see how Mendelssohn in his reflections on that topic basically anticipates ideas of the late 20th century reception aesthetics).

Mendelssohn himself began working on a refutation (Gegenbetrachtungen) immediately after he had received the delivery, but he did not send a reply to Lavater's dedication until December. In his letter of December 26, he rejected the alternative of either philosophical refutation or religious conversion with all bluntness and professed his fidelity to the essential tenets of Judaism. The fact that Mendelssohn did so for the first time in publicthe fact that he felt forced to do so-is probably the most meaningful and most problematic aspect of the whole affair. Until then, Mendelssohn had appeared in public exclusively as an Enlightenment philosopher and had considered and cultivated his Jewish religion as a totally private matter. Never had he published as a Jewish author, and the Enlightenment circles in Berlin had respected this. ${ }^{31}$ Now, in reply to Lavater, Mendelssohn could reject the public call to conversion, but he could not reject the public address as a Jew. Addressed as a Jew, Mendelssohn had to respond as a Jew. In other words, the "German Socrates" had become-was made - the Jewish philosopher through Lavater's dedication. ${ }^{32}$

Mendelssohn did not conceal the awkward position this had put him in, both vis-àvis his own Jewish community and Berlin's learned society. He repeatedly emphasized that he did not want to engage in religious disputes (Religionsstreitigkeiten). Nevertheless, in his response letter to Lavater (Rabidowicz 1974, pp. 5-17), he referred to important teachings of the Jewish tradition; for example, to the fact that Judaism had no interest or intent to convert others (something that seems not to have been clear to Christians of that time) and to the superiority of halakhic laws over miracle stories with regard to the faithfulness of Judaism. To an even greater extent, Mendelssohn argued from within the Jewish tradition in his "Gegenbetrachtungen", which he held at the ready but preferred not to publish as a response to Lavater ([1764] 1997, pp. 67-121). The actual conflict was 
then resolved - not least thanks to the mediation of influential Enlightenment thinkers in Berlin-in such a way that Mendelssohn was not forced to publish a detailed refutation. Instead, the two protagonists agreed to publish their correspondence together under the title "Briefe von Herrn Moses Mendelssohn und Joh. Caspar Lavater" in order to settle the public controversy. To this co-publication, Mendelssohn contributed "Nacherinnerungen," written in a conciliatory tone and revealing nothing of the sharpness he expressed in the "Gegenbetrachtungen". Only once he would address Lavater directly again. ${ }^{33}$ However, the whole affair had immense consequences for Mendelssohn's life (more, it seems, than for Lavater's), as it provoked a physical and psychological collapse from which he may not have recovered until his death. We cannot know with certainty whether there was a direct connection between his forced "coming out" as a Jew and the fact that Emperor Friedrich II refused to admit Mendelssohn to the Academy of Sciences in 1771, as some of Mendelssohn's Berlin friends assumed. However, we do know that after the Lavater affair, Mendelssohn began to publish as a Jewish author. One way to cope with his crisis was to work on his book Jerusalem oder über religiöse Macht und Judentum, published in 1783 - a book with which Mendelssohn explicitly emerged as a Jewish author, especially in the second part (Altmann 1983, pp. 99-204). Many thoughts are elaborated in this work that Mendelssohn had first expressed during the affair with Lavater, and indeed his Jerusalem has been read as a replay of his controversy with the Swiss pastor ("seine lang erwartete, schon Ende 1769, gelegentlich des Lavater-Streits von Herder erbetene confessio judaica;" Altmann 1983, XXIII). Moreover, Lavater serves as a representative figure of the dominant Christian religion who does not or cannot admit that "Christianity is built upon Judaism and so, if the latter tumbles, the former will necessarily fall over it in one heap of rubble" ("Nun ist das Christentum, wie Sie wissen, auf dem Judentume gebauet, und muß nothwendig, wenn dieses fällt, mit ihm über einen Hauffen stürzen” Altmann 1983, p. 154).

In view of these observations, it is certainly not an exaggeration to state that the controversial open letter dialogue with Lavater was the starting point of Mendelssohn's public activity as a Jewish author (Rabidowicz 1974, CV). It may sound strange, and it was undoubtedly accompanied by great personal suffering, but without the Lavater affair, Mendelssohn probably might not have become the mastermind of modern religious Jewish thought, and founder of the Haskalah, that he is generally regarded as today (see Sacks 2017).

Lavater likewise did not address Mendelssohn directly later on. However, there are some references in his works, the most explicit being the dedication of his apologeticalprotreptic "Nathanael" to Johann Wolfgang Goethe shortly after the death of Moses Mendelssohn in January 1786. In this dedication, Lavater refutes to reveal whom he actually had in mind with the dedication, and he calls this an act of repentance for "a similar dedication which 15 years earlier is said to have given the first death blow to a sage of this world". 34

Hence, the results of the controversy, painful as it was for Mendelssohn in particular, were two dogmatical treatises-a Jewish one and a Christian one-that can be interpreted as a kind of continuous dialogue: Mendelssohn's Jerusalem and Lavater's Nathanael. Both protagonists reflected and reworked their direct confrontation and built up their own religious ideas from that basis, including and using the other in service of their own teachings. By the end, Mendelssohn had articulated Judaism as an explicitly particular religion without any missionary ambitions, whereas Lavater made Christianity's universalist claim increasingly clear and insisted on the important role Jews played for the chiliastic hope of Christian pietists.

The Lavater-Mendelssohn case is instructive in several respects with regard to how religious co-production through dialogue works. During the immediate confrontationthe "real" dialogue, if you like-both sides repeatedly demanded that the other change perspectives, to imagine the situation of the respective other, to include the second-person perspective. ${ }^{35}$ Interestingly, this demand was always related to the authors' social standing and recognition. At the same time, the two protagonists engaged in an indirect dialogue 
with each other, which becomes visible in their correspondences with others and their later publications. In this indirect dialogue, each uses the other to develop his own religious identity by making the other a figure shaped by himself for the sake of his own religious self-reflection and identity formation. To put it in Buber's words: each transformed the $D u$ into an Es and thereby formed his own religious identity-and that of his sympathetic audience-in productive interaction with that $E s$, itself shaped from the direct dialogical confrontation with the $D u$.

\section{Epistemological and Ethical Conclusions}

Different types of religious co-production can be observed in history. ${ }^{36}$ Literary dialogues provide an intellectual or meaning-focused mode of co-production. Authors include the second-person perspective by creating it according to the need to explore and present their own religious identities. Depending on the given place and time, figures of religious otherness in literary dialogues have to be at least plausible to readers, because otherwise the dialogue would not achieve its goal of providing orientation with regard to religious diversity. Thus, Justin had to make his Trypho a plausible Jew if he wanted his readers to understand the differences between Jews and Christians. Halevi had to present his Edomite and Ishmaelite in the awareness that his readers might encounter Christians and Muslims every day. Lavater had to involve Mendelssohn in the editing of their correspondence after the storm of reactions to his delicate dedication in order to preserve his credibility and to limit the damage done to his reputation among leading scholars of his time. However, there were also times and places in history when Christians could write and read such dialogues without ever encountering a real Jew or Muslim at all. Peter Alfonsi's target audience probably had little contact with real Jews and Muslims, and the fact that Alfonsi came from Andalusia provided him at the same time with an aura of special knowledge and a greater freedom in shaping his religious others for his Latin Christian readers (in fact, his case shows that personal involvement not always causes more authentic and emphatic perceptions and presentations of the religious other, as we tend to presuppose today). For all of them, it is true to varying degrees that they not only shaped the identity of their own religious communities, but also the perceptions of others. The perception of religious others, in turn, has an impact on interactions in real life. Hence, religious co-production does not remain confined to the realm of literature and intellectual competition but also effects actual history "on the ground".

The cases I have presented here are not isolated or accidental moments in the long history of mutual co-production in Judaism, Islam, and Christianity. They are rather inscribed within a large history of narratives and claims of inheritance, supersession, appropriation, and detachment, and those narratives and claims have served political rulers and religious authorities to legitimate suppression and violence both physical and structural. The history of Christians, Muslims, and Jews indeed offers more than enough material to explore the ambivalent potentials of religious co-production. Therefore, to think about relations between Muslims, Jews and Christians in terms of co-production means to activate both the critical and the constructive function of historical reasoning. This is far more challenging - but also, I assume, far more useful—than to simply use past events as simplistic exempla for present issues-as repeatedly happens with the second century Roman Empire as the archetype for polytheistic religious tolerance, with medieval Spain as the golden age of convivencia and with the Enlightenment movement as the mastermind of religious freedom. ${ }^{37}$ Thinking in terms of the co-production of Muslims, Jews, and Christians demands that we focus on the painful as well as the beautiful processes and outcomes of their entangled pasts and presents-and futures.

What almost all written dialogues have in common is that they state a friendly relationship between the dialogue partners at the outset, and their dialogues also end with an emphasis on friendship. Friendly exchange between the characters is a requirement of the literary genre. However, we should not be too quick to dismiss this as a literary topos, for every literary topos also has its epistemological value. We could even state that 
the very choice of dialogical confrontation testifies to an author's awareness of how much different religious traditions owe to each other. This is perhaps also the reason why so many controversial dialogues have an open end and why tolerance is so often explicitly demanded at the end of literary religious dialogues. Can we conclude that dialogue authors regarded the existence of religious Others essential and even necessary for the shaping of their own religious traditions?

Of course, the rhetoric of friendship should not obscure the fact that religious coproduction is always co-determined by concrete social and political power relations. This becomes particularly clear in the Lavater-Mendelssohn affair. The understanding that Mendelssohn eventually emerged from this confrontation as the first Jewish philosopher in public and that without Lavater's dedication he might never have written his Jerusalem, which became the program of enlightened Judaism, must not whitewash the immense personal suffering, danger, and loss with which this was connected. In order not to fall into the cruel traps of teleological interpretations of interreligious co-production, it is crucial to combine the longue-durée perspective with the micro-level analysis of history.

Finally, as history teaches us that religious co-production is as inevitable as it is ambivalent, and in view of the epistemological necessity and ethical risk of religious co-production, I would like to raise the following questions (without trying to disguise their rhetorical character): is it too simplistic to state that the historical fact of religious co-production teaches us how much religious traditions, groups, and individuals owe to their religious others, for better or worse? Is it too arbitrary then to conclude from this historical fact of co-production that the more convinced and the more content someone is with their own religious tradition, the more they should be thankful to the others who helped shape it? And is it too moralistic then to require that the more thankful someone is in awareness of the effects of co-production, the clearer should be their commitment to the flourishing of the religious others as the natural and essentially needed partners of mutual identity formation?

Paul Mendes-Flohr concluded his reflections on a strong notion of dialogical tolerance in his Dialogue and the crafting of multi-cultural society by quoting Hannah Arendt: "For respect for human dignity implies the recognition of my fellow-men-or our fellownations as subjects, indeed, as builders of the world, as co-builders of a common world" (Arendt 1951, p. 458), quoted in Mendes-Flohr 2017, p. 309). Mendes-Flohr takes this as a secular affirmation that common creatureliness should be the decisive stimulus for a strong religious tolerance, which should take seriously not only the similarities but also the differences between the tenets and traditions of different religions. I would like to add that, given their entangled history of conflictual coexistence and the resulting hermeneutics, Muslims, Jews, and Christians are not only co-builders of a common world, but they were and still are and will be co-builders of their respective religious identities. Strong dialogical tolerance is therefore not only crucial because pluralistic societies require religious tolerance in order to secure peaceful coexistence, but also for a quite "selfish" reason, namely-to put Buber's dialogical principle in a Kantian mode-because the existence of a strong religious other is the condition for the possibility of dialogical self-production.

Funding: This research received no external funding.

Institutional Review Board Statement: Not applicable.

Informed Consent Statement: Not applicable.

Data Availability Statement: This study did not report any data.

Acknowledgments: My thanks are due to David Nirenberg as well as to Maria Lissek, Christina Torrey, and Steffen Götze for their most encouraging and valuable comments on the manuscript. Carson Bay not only provided helpful advice on the content, but also took care of the linguistic and formal revision of the article. And thanks to Bern student Judith Neuenschwander for drewing my attention to the very interesting case of Lavater and Mendelssohn.

Conflicts of Interest: The author declares no conflict of interest. 


\section{Notes}

1 Since many historians have been researching interactions between Muslims, Jews, and Christians in recent decades, it may appear very obvious to speak of "religious co-production." However, the concept of co-production has not yet been systematically elaborated. The interest to fill this gap I share with David Nirenberg (see Nirenberg 2014, pp. 1-13), and we will foster in-depth work on the historical dynamics and hermeneutical potentials of religious co-production within our joint research project "Interactive Histories, Co-produced Communities: Judaism, Christianity and Islam," starting in the autumn of 2022. A comprehensive history of controversial dialogues is still waiting to be written. For a very short overview see (Heyden 2011). Inter-religious Think-Tank, Guidelines for Inter-Religious Dialogue. Practical suggestions for successful interfaith dialogue. Online book: https:/ / onlinebooks.io/guidelines-for-inter-religious-dialogue/ (accessed on 14 January 2022).

4 See Buber (1923) and also "Zwiesprache," “Die Frage an den Einzelnen," and "Elemente des Zwischenmenschlichen," in Buber (1973).

5 Buber (1923, 43ff): “In bloßer Gegenwart läßt sich nicht leben, sie würde einen aufzehren, wenn da nicht vorgesorgt wäre, daß sie rasch und gründlich überwunden wird. ( . . . ) Und in allem Ernst der Wahrheit, du: ohne Es kann der Mensch nicht leben. Aber wer mit ihm allein lebt, ist nicht der Mensch".

6 For medieval Christian dialogues, this has been shown by Lissek (2022). Lissek also provides a methodology that can be generally applied to other literary dialogues.

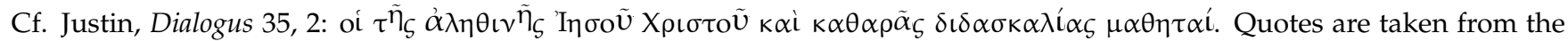
critical edition of Bobichon (2003).

8 Diversity among Jewish and Christian groups is assumed throughout the dialogue, but there also appear lists of Jewish and Christians sects: Justin, Dialogus 35.80. On Jewish groups in the Dialogus see (Boyarin 2001; Bobichon 2002; Choi 2010; White 2018; Stantin 2018; Edsall 2021).

9 For a brief summary of that discussion, see (Lieu 1996, pp. 103-53), who herself assumes Christians and pagan proselytes. Most recently, den Dulk 2018 has argued very strongly for a Christian readership with reference to the "Demiurgical sects", but see the critical review by Paget (2020).

Justin, Dialogus 142: [Trypho]: “We have found more than we expected, and more than it was possible to have expected. And if we could do this more frequently, we would benefit in the searching of the Scriptures themselves. But since," he said, "you are on the eve of departure, and expect daily to set sail, do not hesitate to remember us as friends when you are gone." "For my part," I [Justin] replied, "if I had remained, I would have wished to do the same thing daily."

Eusebius of Caesarea, Historia ecclesiastica 4.18.2-9 says that the Dialogus goes back to a conversation Justin had in Ephesus during the Bar Kokhba revolt. On the historicity of Trypho see (Lieu 1996, pp. 109-13).

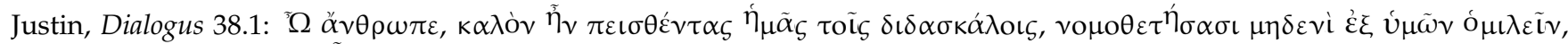

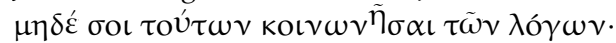

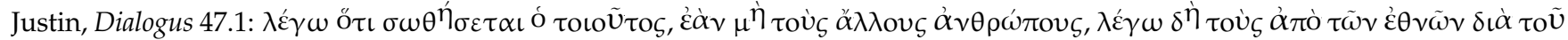

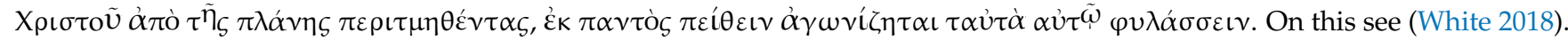
The reception and influence of both books has been well documented. For the reception of Alfonsi see (Tolan 1993); on Halevi see (Shear 2008).

The only scholars to have compared Halevi and Alfonsi so far, though only vaguely, are to my knowledge (Tolan 1993), and (Hasselhoff 2014, 71ff).

Petrus Alfonsi, Dialogus Prol. 5: Hunc igitur libellum composui, ut omnes et meam cognoscant intentionem et audiant rationem.

The king is called the Kuzari, and this has become also the most common title of the work. I use the name Kuzari as reference to the work here, bearing in mind that the king is the main "seeker character" in the work.

Halevi, Kuzari I.1: "I was repeatedly asked what arguments and replies I could bring to bear against the attacks of philosophers of other religions (אנשי התורות), and also against Jewish sectarians who attacked the rest of Israel (המינים החולקים על המון ישראל)." Shear (2008), xi rightly emphasizes that the Kuzari is "much more than a defense of Talmudic authority against internal Jewish sectarian opponents." See Oesterreicher (1903, pp. 3-40), who identified references to 38 haggadic texts in Alfonsi; more recently, see Hasselhoff (2014). Petrus Alfonsi, Dialogus Prologus II.I.9: quod si aliquam de Scripturis auctoritatem attuleris, secundum ueritatem Hebraicam hoc facere uelis. Quod si aliter facias, me non recepturum esse agnoscas.

With this, Alfonsi sets new standards for Christian controversy with Judaism, because since late antiquity Christian polemics had always referred to the text of the Septuagint, and Jews engaging with the Hebrew text often prevailed in Scriptural disputes as a result.

See (Schwagmeier 2014, p. 134): “Petrus will ganz offensichtlich möglichst alle Texte der Hebräischen Bibel einbeziehen: Das ganze Alte Testament zeugt von Christus."

23 Petrus Alfonsi, Dialogus Prologus 5: et quod eum Iudei crucifixerunt sua dispositione et uoluntate, ut, sicut erat creator, fieret et redemptor totius sancte ecclesie fidelium, scilicet precedentium et sequentium. 
Petrus Alfonsi, Dialogus Titulus V.1: Semper enim, ut dixi, cum eis conuersatus et innutritus es, libros legisti, linguam intelligis. See Forster (2014).

For the reception of Halevi see (Kogan 2003; Schwartz 2004; Dauber 2012). For the reception of Alfonsi see Tolan (1993) and the five last chapters in Cardelle de Hartmann and Roelli (2014, pp. 227-369).

Lavater ([1764] 1997, pp. 38-39); see Hirzel (2002, pp. 133-35). To my understanding, Hirzel's account of Lavater's intentions is too apologetic and influenced by Lavater's self-portrayal. For example, Hirzel suggests that the decision to dedicate the work to Mendelssohn was rather accidental, that it was only because of time constraints that Lavater did not have it printed in the Swiss edition, and that he could not have foreseen the difficulties the dedication would pose for Mendelssohn. One could argue that Lavater should have indeed expected much worse, since the social status and reputation of Jews in Zurich was even worse than in relatively progressive Berlin that time. (As a matter of fact, Jews had no access to the city of Zurich until 1787). The fact that Lavater did not have the dedication to a Jew in Switzerland printed could therefore also have been out of consideration for his own reputation.

“ ... daß ich es wagen darf, Sie zu bitten, Sie vor dem Gotte der Wahrheit, Ihrem und meinem Schöpffer und Vater zu bitten und zu beschwören: Nicht, diese Schrift mit philosophischer Unparteylichkeit zu lesen; denn das werden Sie gewiß, ohne mein Bitten, sonst thun." (Hirzel 2002, p. 234).

The phrase "Service of the Jews" was established by Anna Sapir Abulafia with regard to medieval Christianity; see Abulafia $(2011,2013,2014)$.

Mendelssohn himself pointed to that idea in his “Was ihn zu diesem Schritte bewogen?" (Rabidowicz 1974, 63ff) with unmistakable sarcasm: "Gesegnet sey die Asche des menschenfreundl. Theologen, der zuerst gesagt, Gott erhielt uns als einen sichtbaren (Beweis = von der W. der N. Religion. ( . . . ) Es läßt sich freylich nicht begreiffen, warum uns die N. bekehren, und also den sichtbaren Beweis ihres Glaubens vernichten wollen" (p. 64).

Letter of Lavater to Mendelssohn from September 26, 1769: “qu'il ne nous paroissoit pas convenable de dédier à un Juif calculé uniquement pour les Incrédules néd dans le sein de de l'Eglise;" (Luginbühl-Weber 1997, p. 40).

31 This is to be seen, for example, in Lessing's short essay "Über das Lustspiel Die Juden," in which he anonymously quotes a letter "from a Jew" to demonstrate the high education and noble mindset of the Jews. This letter turns out to be written by Moses Mendelssohn to Johann David Michaelis on October 16, 1754 (Stenzel 1989, pp. 489-97). For this reference I thank Steffen Götze (University of Bern).

After Mendelssohn had published his "Phaedon oder über die Unsterblichkeit der Seele" in 1763, he was called the "German or Berlin Socrates."

"Letter of Moses Mendelssohn to Lavater from April 14, 1775," FA Lav Ms 520 nr. 88. In this letter, Mendelssohn begged Lavater to intercede on behalf of the Jews in the Swiss village of Lengnau.

34 Lavater (1786, p. 5): “Und durch diese wirkliche Diskretion jene scheinbare Indiskretion einer ähnlichen Zuschrift büssen, die vor wohl fünfzehn Jahren einem Weisen dieser Welt, der im Jenner 1786. Starb, den ersten Todesstoß gegeben haben soll.” This last accusation was made by Friedrichh Nicolai against Lavater; see (Altmann 1998, p. 234).

35 Mendelssohn, in his letter to Lavater from december 12, 1769: "Sie können sich unmöglich in die Gedanken eines solchen versetzt haben, der die Überzeugung nicht mitbringet, sondern in diesem Werk erst suchen soll” (Hirzel 2002, p. 248); “Wenn Sie sich an meine Stelle setzen, und die Umstände nicht aus Ihrem Gesichtspunkte, sondern aus dem Meinigen betrachten, so werden Sie meiner Neigung Gerechtigkeit widerfahren lassen" (Hirzel 2002, p. 249). Lavater in his letter to Mendelssohn from February 20, 1770: "Setzen Sie sich an die Stelle eines christl. Predigers, der alle acht Tage in einer Stadt, die nicht den vierten Theil so groß ist, als Berlin gegen Laster $\mathrm{u}$. Vorurtheile kämpft-sich häufige Feinde macht, und öffentl. so gar von einem Juden des Nichthaltens eines Versprechens wenigstes indirecte beschuldigt wird" (Hirzel 2002, p. 164).

36 At a most concrete level, sexual relations between members of different religious groups and children that are born from mixed marriage can be seen as a type of religious co-production; at a socio-political level, all kinds of appropriation and adaption can be called co-production (consider, for instance, rituals at shared religious places); at a discursive level, all outcomes of intellectual exchange and confrontation, be they in real or in invented encounters, can be perceived as co-production.

References for such claims and critical assessments include, for the Roman Empire, (Gibbon 1788); for medieval Spain, see (Nirenberg 1998, 2011, 2014).

\section{References}

Abulafia, Anna Sapir. 2011. Christian Jewish Relations 1000-1300: Jews in the Service of Medieval Christendom. London: Routledge.

Abulafia, Anna Sapir. 2013. The Service of Jews in Christian-Jewish Disputations. In Les Dialogues 'aduersus Iudaeos': Permanences et mutations d'une tradition polémique. Actes du colloque international organisé les 7 et 8 décembre 2011 à l'Université de Paris-Sorbonne. Edited by Sébastien Morlet, Olivier Munnich and Bernard Pouderon. Paris: Institut d'Études Augustiniennes, pp. 339-49.

Abulafia, Anna Sapir. 2014. Moyses in Service of Petrus in Petrus Alfonsi's Dialogus. In Petrus Alfonsi and his Dialogus: Background, Context, Reception. Edited by Carmen Cardelle de Hartmann and Philipp Roelli. Florence: SISMEL, pp. 111-28.

Altmann, Alexander. 1983. Moses Mendelssohn, Band VIII: Schriften zum Judentum II. Berlin: Faksimile-Neudruck.

Altmann, Alexander. 1998. Moses Mendelssohn: A Biographical Study. Oxford: Oxford University Press. 
Arendt, Hannah. 1951. The Origins of Totalitarianism. New York: Schocken.

Becker, Adam, and Annette Yoshiko Reed. 2003. The Ways that Never Parted: Jews and Christians in Late Antiquity and the Early Middle Ages. Tübingen: Mohr Siebeck.

Bobichon, Philippe. 2002. Autorités religieuses juives et «sectes» juives dans l'œuvre de Justin Martyr. Revue des Études Augustiniennes 48: 3-22. [CrossRef]

Bobichon, Philippe. 2003. Dialogue avec Tryphon, édition critique. Introduction, Texte grec, Traduction, Commentaires. Fribourg: Editions universitaires de Fribourg, vol. 2.

Bonnet, Charles. 1769. La Palingénésie Philosophique ou Idées sur l'Etat passé et L'Etat Futur des Etres Vivans: Ouvrage destiné à servir de Supplement aux derniers Ecrits de l'Auteur, et qui contient principalement le Précis de ses Recherches sur le Christianisme. Geneva: Claude Philibert et Barthelemi Chirol, vol. 2.

Bonnet, Charles. 2002. La Palingénésie philosophique. Edited by Christiane Frémont. Paris: Fayard.

Boyarin, Daniel. 2001. Justin Martyr Invents Judaism. Church History 70: 427-61. [CrossRef]

Buber, Martin. 1923. Ich und Du. Stuttgart: Reclam.

Buber, Martin. 1973. Das dialogische Prinzip. Heidelberg: Lambert Schneider.

Cardelle de Hartmann, Carmen, and Philipp Roelli. 2014. Petrus Alfonsi and his Dialogus: Background, Context, Reception. Florence: SISMEL.

Choi, Michael J. 2010. What is Christian Orthodoxy according to Justin's Dialogue? Scottish Journal of Theology 63: 398-413.

Dauber, Jonathan. 2012. Knowledge of God in the Development of Early Kabbalah. Leuven: Peeters.

den Dulk, Mathijs. 2018. Between Jews and heretics: Refiguring Justin Martyr's Dialogue with Trypho. London: Routledge.

di Cesare, Michelina. 2014. Petrus Alfonsi and Islamic Culture: Literary and Lexical Strategies. In Petrus Alfonsi and his Dialogus: Background, Context, Reception. Edited by Carmen Cardelle de Hartmann and Philipp Roelli. Florence: SISMEL, pp. $203-25$.

di Cesare, Michelina. 2015. Sapiens minime hujusmodi paradisum credit, nec talibus decipitur verbis: Pietro Alfonsi e gli Arabes. In Paradossi delle Notti: Dieci studi su Le Mille e Una Notte. Edited by Leonardo Capezzone and Elisabetta Benigni. Pisa: Fabrizio Serra Editore, pp. 79-99.

Dunn, James D. G. 2008. The Parting of the Ways Between Christianity and Judaism and Their Significance for the Character of Christianity. London: SCM.

Edsall, Benjamin. 2021. Scribes, Pharisees, Sadducees, and Trypho: Jewish Leadership and Jesus Traditions in Justin's Construal of Christian and Jewish Identity. In The Reception of Jewish Tradition in the Social Imagination of the Early Christians. Edited by John M. G. Barclay and Kylie Crabbe. New York: Bloomsbury, pp. 145-48.

Forster, Regula. 2014. Der abwesende Dritte: Die Darstellung des Islam im titulus V des Dialogus des Petrus Alfonsi. In Petrus Alfonsi and his Dialogus: Background, Context, Reception. Edited by Carmen Cardelle de Hartmann and Philipp Roelli. Florence: SISMEL, pp. 159-82.

George, Tobias. 2012. Justin's School in Rome-Reflections on Early Christian 'Schools'. Zeitschrift für Antikes und Christentum 16: 75-87. [CrossRef]

Gibbon, Edward. 1788. The History of the Decline and Fall of the Roman Empire. London: Strahan \& Cadell, vol. 6.

Halper, Yehuda. 2017. Socrates and Socratic Philosophy in Judah Halevi's Kuzari. Jewish Quarterly Review 107: 447-75. [CrossRef]

Harnack, Adolf. 1913. Judentum und Judenchristentum in Justins Dialog mit Trypho. Leipzig: J. C. Hinrichs.

Hasselhoff, Görge K. 2014. Petrus Alfonsis Judentum vor dem Hintergrund seiner Zeit. In Petrus Alfonsi and his Dialogus: Background, Context, Reception. Edited by Carmen Cardelle de Hartmann and Philipp Roelli. Florence: SISMEL, pp. 61-76.

Heyden, Katharina. 2009. Christliche Transformation des antiken Dialogs bei Justin und Minucius Felix. Zeitschrift für Antikes Christentum 13: 204-32. [CrossRef]

Heyden, Katharina. 2011. Dialogue. In Encyclopedia of the Bible and its Reception. Edited by Christine Helmer, Steven L. McKenzie, Thomas Römer, Jens Schröter, Barry Walfish, Eric Jozef Ziolkowski, Dale C. Allison and Hans-Josef Klauck. Berlin: De Gruyter vol. 4, pp. 736-40.

Hirzel, Martin. 2002. Johann Caspar Lavater-Ausgewählte Werke, Band III: Werke 1769-1771. Zurich: NZZ Verlag.

Holthaus, Stephan. 2009. Judenmission im Pietismus und in der Erweckungsbewegung: Ein Überblick. In Christen, Juden und die Zukunft Israels: Beiträge zur Israellehre aus Geschichte und Theologie. Edited by Berthold Schwarz and Helge Stadelmann. Edition Israelogie 1. Frankfurt: Peter Lang, pp. 153-84.

Hughes, Aaron William. 2007. The art of philosophy: The use of dialogue in Halevi's 'Kuzari' and Abravanel's 'Dialoghi d'amore. Medieval Encounters 13: 470-98. [CrossRef]

Kogan, Barry Sherman. 2003. Judah Halevi and his use of philosophy in the 'Kuzari'. In The Cambridge Companion to Medieval Jewish Philosophy. Edited by Daniel F. Frank and Oliver Leaman. Cambridge: Cambridge University Press, pp. 111-35.

Lang, T. J. 2016. Intellect Ordered: An Allusion to Plato in Dialogue with Trypho and its Significance for Justin's Christian Epistemology. The Journal of Theological Studies 67: 77-96. [CrossRef]

Langermann, Y. Tzvi. 1997. Science and the Kuzari. Science in Context 10: 495-522. [CrossRef]

Lavater, Johann Caspar. 1786. Nathanaél: Oder, die eben so gewisse, als unerweisliche Göttlichkeit des Christenthums. Für Nathanaéle, Das ist, Für Menschen mit geradem, gesundem, ruhigem, Truglosem Wahrheitssinne. Basel: Emanuel Thurneysen.

Lavater, Johann Caspar. 1997. Reisetagebücher, Band I: Tagebuch von der Studien- und Bildungsreise nach Deutschland 1763 und 1764. Edited by Horst Weigelt. Texte zur Geschichte des Pietismus VIII.3. Göttingen: Vandenhoeck \& Ruprecht. First published 1764. 
Lavater, Johann. 1769. Herrn Carl Bonnets, verschiedener Akademieen Mitglieds, philosophische Untersuchung der Beweise für das Christenthum: Samt desselben Ideen von der künftigen Glückseligkeit des Menschen. Zürich: Füesslin \& Compagnie.

Lieu, Judith. 1996. Image and reality: The Jews in the world of the Christians in the Second Century. Edinburgh: T\&T Clark.

Limor, Ora, and Guy G. Stroumsa. 1996. Contra ludaeos: Ancient and Medieval Polemics between Christians and Jews. Tübingen: Mohr Siebeck.

Lissek, Maria. 2022. Sich selbst durch andere verstehen: Die Kontroversdialoge von Gilbert Crispin und Petrus Alfonsi. Paderborn: Brill.

Luginbühl-Weber, Gisela. 1997. Johann Kaspar Lavater-Charles Bonnet_Jacob Benelle: Briefe 1768-1790: Ein Forschungsbeitrag zur Aufklärung in der Schweiz-I. Halbband: Briefe. Bern: Peter Lang.

Mach, Michael. 1996. Justin Martyr's Dialogus cum Tryphone ludaeo and the Development of Christian Anti-Judaism. In Contra ludaeos: Ancient and Medieval Polemics between Christians and Jews. Edited by Ora Limor and Guy G. Stroumsa. Tübingen: Mohr Siebeck, pp. 27-47.

Malachi, Ariel. 2018. Scepticism at the Service of Revelation? Preliminary Observations on Logic and Epistemology in Judah Halevi's Kuzari. In Scepticism and Anti-Scepticism in Medieval Jewish Philosophy and Thought. Edited by Racheli Haliva. Berlin: De Gruyter pp. 23-40.

Martin, Lucinda. 2012. Anti-Judaism and Philo-Judaism in the Pietist Periodical. Seminar: A Journal of Germanic Studies 48: 301-16. [CrossRef]

Mendes-Flohr, Paul. 2017. Dialogue and the Crafting of a Multi-Cultural Society. In Responsibility and the Enhancement of Life: Essays in Honor of William Schweiker. Edited by Günther Thomas and Heike Springhart. Leipzig: Evangelische Verlagsanstalt, pp. 309-17.

Morlet, Sébastien, Olivier Munnich, and Bernard Pouderon. 2013. Les Dialogues 'aduersus Iudaeos': Permanences et mutations d'une tradition polémique. Actes du colloque international organisé les 7 et 8 décembre 2011 à l'Université de Paris-Sorbonne. Paris: Institut d'Études Augustiniennes.

Nirenberg, David. 1998. Communities of Violence: Persecution of Minorities in the Middle Ages. Princeton: Princeton University Press.

Nirenberg, David. 2011. Die moderne Vorbildfunktion des mittelalterlichen Spanien. Münchner Beiträge zur Jüdischen Geschichte und Kultur 2: 7-29.

Nirenberg, David. 2013. Anti-Judaism. The Western Tradition. New York: Head of Zeus.

Nirenberg, David. 2014. Neighboring Faiths. Christianity, Islam and Judaism in the Middle Ages and Today. Chicago: The University of Chicago Press.

Oesterreicher, Josef. 1903. Die Gespräche des Petrus Alfonsi und ihhre haggadischen Bestandteile. Jahresbericht der Deutschen LandesOberrealschule Göding 5. Göding: Deutschen Landes-Oberrealschule.

Paget, James C. 2020. Review of Mathijs den Dulk, "Between Jews and Heretics". The Journal of Ecclesiastical History 71: 378-80. [CrossRef]

Parvis, Sara, and Paul Foster. 2007. Justin Martyr and his Worlds. Minneapolis: Fortress.

Rabidowicz, Simon, ed. 1974. Moses Mendelssohn, Band VII: Schriften zum Judentum I. Berlin: Faksimile-Neudruck.

Ravitzky, Aviram. 2019. Ibn Gabirol and Judah Ha-Levi's Usage of Dialogue: The Role of the Disciple in 'Fons Vitae' and That of the King in 'Kitāb Al-Khazarī',. Religion 10: 549. [CrossRef]

Sacks, Elias. 2017. Moses Mendelssohn's Living Script: Philosophy, Practice, History, Judaism. Bloomington: Indiana University Press.

Schwagmeier, Peter. 2014. Zu den alttestamentlichen Bibelzitaten im Dialogus. In Petrus Alfonsi and his Dialogus: Background, Context, Reception. Edited by Carmen Cardelle de Hartmann and Philipp Roelli. Florence: SISMEL, pp. 129-58.

Schwartz, Yossef. 2004. Zwischen Philosophie und Theologie im 12. Jahrhundert: Halevi, Ibn Daud und Maimonides. In Metaphysics in the Twelfth Century: On the Relationship among Philosophy, Science and Theology. Edited by Lutz Bachmann, Alexander Fidora and Andreas Niederberger. Turnhout: Brepols, pp. 113-35.

Schweid, Eliezer. 2007. The Khazar Motif in the Kuzari of Judah Halevi. In New Perspectives: Selected Papers from the Jerusalem 1999 International Khazar Colloquium. Edited by Peter Golden, Haggai Ben-Shammai and András Roná-Tas. Leiden: Brill, pp. 279-90.

Shear, Adam. 2008. The Kuzari and the Shaping of Jewish Identity, 1167-1900. Cambridge: Cambridge University Press.

Sorkin, David. 1998. Moses Mendelssohn and the Religious Enlightenment. Berkeley: University of California Press.

Stantin, G. 2018. Justin Martyr's Dialogue with Trypho: Group boundaries, 'proselytes' and 'God-fearers'. In Tolerance and Intolerance in Early Judaism and Christianity. Edited by G. Stanton and Guy Stroumsa. Cambridge: Cambridge University Press, pp. $263-78$.

Stenzel, Jürgen. 1989. Gotthold Ephraim Lessing: Werke in zwölf Bänden-Band 1. Frankfurt: Deutscher Klassiker Verlag.

Tolan, John. 1993. Peter Alfonsi and his Medieval Readers. Gainesville: University Press of Florida.

Ulrich, Jörg. 2012. What Do We Know about Justin's 'School' in Rome? Zeitschrift für Antikes Christentum 16: 62-74. [CrossRef]

Vogt, Peter. 2007. Zwischen Bekehrungseifer und Philosemitismus: Texte zur Stellung des Pietismus zum Judentum. Leipzig: Evangelische Verlagsanstalt.

White, Benjamin. 2018. Justin between Paul and the Heretics: The Salvation of Christian Judaizers in the Dialogue with Trypho. Journal of Early Christian Studies 26: 163-89. [CrossRef] 